\title{
Moulting juvenile male southern elephant seals Mirounga leonina (L.) at Hannah Point, Walker Bay, Livingston Island, South Shetland Islands
}

\author{
ELIZABETH CRUWYS and PAMELA B. DAVIS
}

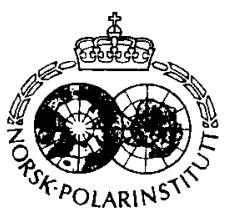

\begin{abstract}
Cruwys, E. \& Davis, P. B. 1995: Moulting juvenile male southern elephant seals Mirounga leonina (L.) at Hannah Point, Walker Bay, Livingston Island, South Shetland Islands. Polar Research 14(3), 329-333.

Southern elephant seals Mirounga leonina (L.) were counted at seventeen discrete moulting sites at Hannah Point, Walker Bay on Livingston Island in the South Shetland Islands between 2 January and 16 February 1994. The physical characteristics of each moulting site were assessed. Counts through 46 consecutive days demonstrated that the number of juvenile males in dry moulting sites increased as the muddy wallows were gradually abandoned. This pattern of behaviour is similar to the pattern described for other sex-and agegroups (e.g. adult females) in previous studies.
\end{abstract}

E. Cruwys, Department of Zoology, University of Cambridge, New Museums Site, Downing Street, Cambridge CB2 3EJ, UK; P. B. Davis, Scott Polar Research Institute, University of Cambridge, Lensfield Road, Cambridge CB2 IER, UK.

\section{Introduction}

All pinnipeds undergo an annual moulting process (Scheffer 1958; King 1983). Elephant seals in particular are especially notable because of the sloughing off of sheets of cornified epidermis with old hairs (Matthews 1929; Laws 1956; Carrick et al. 1962). During this energy-demanding period (Fay \& Ray 1968; Boyd et al. 1994), pinnipeds often exhibit listless and ill-tempered behaviour (Rand 1967; Wartzok 1991; Cruwys \& Weinstein 1993). This is primarily due to the physiological disturbances which occur during the moult (such as the high peripheral temperature required, reduction in resting metabolic rate, and the fasting or near-fasting conditions observed by some pinnipeds (Boyd et al. 1993).

Southern elephant seals Mirounga leonina (L.) remain ashore for up to 56 days while old hair and skin sloughs away and new hair begins to grow (Laws 1956). Mature adult males tend to haul out for a longer period than younger males and females (Laws 1956; Ling \& Bryden 1981). The timing of the moult in southern elephant seals thus varies among populations and age groups. Adult males tend to moult later than females and juveniles, normally hauling out between the beginning of February and mid-May; cows and juveniles typically moult between November and the end of March, although juveniles tend to arrive and leave earlier than females (Hindell \& Burton 1988; Le Boeuf \& Laws 1994). According to Le Boeuf \& Laws (1994), juvenile elephant seals begin to arrive at Signy Island and Macquarie Island to moult in mid-November. A peak in numbers is reached in mid-December, and most seals have left by late January.

It has been noted that when they first arrive at a beach, southern elephant seals spend some time changing positions until a suitable moulting site (i.e. a location where a number of seals congregate) is found (Matthews 1929; Laws 1956; Carrick et al. 1962). The selection by southern elephant seals of specific sites for moulting and, later, at which to grow new hair, is determined by the physical characteristics of each site. There are two extremes of moulting sites: (1) a "wallow" which is a swampy morass of mud and water, sometimes more than two metres deep, described by Mathew (1929) and Laws (1956); and (2) a "dry site" which is a well-drained area free of mud.

In a study by Fedak et al. (1994), twenty lactating female southern elephant seals were 
marked or radio-tagged at Husvik in South Georgia, and then monitored during moult. It was found that after making landfall, the seals often re-entered the water and sought another moulting site, sometimes many kilometres distant. They remained mobile for several days before settling in a moulting site at some distance from the sea. Once new hair growth begins, an animal often moves to a dry site (Fedak et al. 1994). Tierney (1977), while observing southern elephant seals at the Vestfold Hills in Antarctica. also noted that seals moved between sites while moulting.

In order to test whether juvenile southern elephant seals follow the pattern observed in females by Fedak et al. (1994), seals were observed during the moulting period at Hannah Point. Walker Bay, Livingston Island, South Shetland Islands between 2 January and 16 February 1994.

\section{Study area description}

Hannah Point at Walker Bay $\left(62^{\circ} 39^{\prime} \mathrm{S}, 60^{\circ} 38^{\prime} \mathrm{W}\right)$ is located on the southern central coast of Livingston Island in the South Shetland Islands (Fig. 1A). During most of the austral summer it is free of snow and ice, with the exception of small chunks of ice that were abraded from nearby glaciers by wave action and washed up onto the shore. Hannah Point is a spit of land $1.6 \mathrm{~km}$ long


Fig. 1. Study area. A. The South Shetland Islands, showing the location of Hannah Point in Walker Bay. Livingston Island. B. The position of the seventeen moulting sites $(A-K)$ in the Hannah Point area. At locations A, B. G, I, J, and $K$ there were two moulting sites. The shaded areas represent land covered by glacier; the unshaded areas represent icefree beaches. Triangles represent outcrops of rock and boulders. 
with a ridge about $100 \mathrm{~m}$ high running NW to SE. The terrain is characterised by predominantly hard-packed sand with some moss beds, although the extreme southwestern area comprises flat rocks and stony beaches. Beaches and tussocky grass are the preferred haul-out sites of southern elephant seals (Ling \& Bryden 1981), and although Hannah Point has no tussock grass, there are abundant flat expanses of sand protected from off-shore or on-shore winds by outcrops of rock. In the present study, moulting sites were observed along the whole length of Hannah Point.

\section{Materials and methods}

Southern elephant seals were counted concurrently by three independent observers on 46 consecutive days between 8 a.m. and 10 a.m. Photographs were taken that allowed the stage of the moult process to be determined using the criteria established by Carrick et al. (1962). These are (1) pre-moult, during which changes in location may be made (duration: 9 to 26 days); (2) coat shedding, which lasts 9 to 28 days in immature and sub-adult bulls; and (3) post-moult, which lasts up to 43 days in bulls less than eight years old, and during which the seals move from site to site. The precise location and geographical characteristics of each moulting site were also recorded.
During the period of observation, most seals observed were juvenile males. Following the classification of Laws (1956), these were Class III, "medium size, aged from three to five years, usually sexually mature, but not large enough to take part in the activities of the breeding rookeries", and Class IV, "small and from one to three years old" (Laws 1956, p. 6). Adult females began to arrive mid-January, but numbers remained low throughout the observation period. Only juvenile males were included in this study, partly because they were the most numerous, and partly so as not to mix data for the sexes.

\section{Results and discussion}

The number of juvenile male seals at the study site dropped from 339 on 2 January to 90 on 16 February 1994, with a peak of 371 on 3 January. The seals gathered into seventeen discrete moulting sites at eleven different locations (Fig. 1B). At six locations (A, B, G, I, J, and K), two pods of seals were within ten metres or less of each other and, with the exception of moulting site $G$, occupied identical terrain; seals were observed frequently moving from one to the other, or occupying the area between them. These six locations where seals moved from one part of the site to another are indicated by the addition of lower case letters ( $\mathrm{Aa}, \mathrm{Ab}, \mathrm{Ba}, \mathrm{Bb}$, etc.). Nine moulting
Fig. 2. The number of seals decreasing in wallows and increasing in dry sites between 2 January and 16 February at Hannah Point.
Distribution of seals according to site type

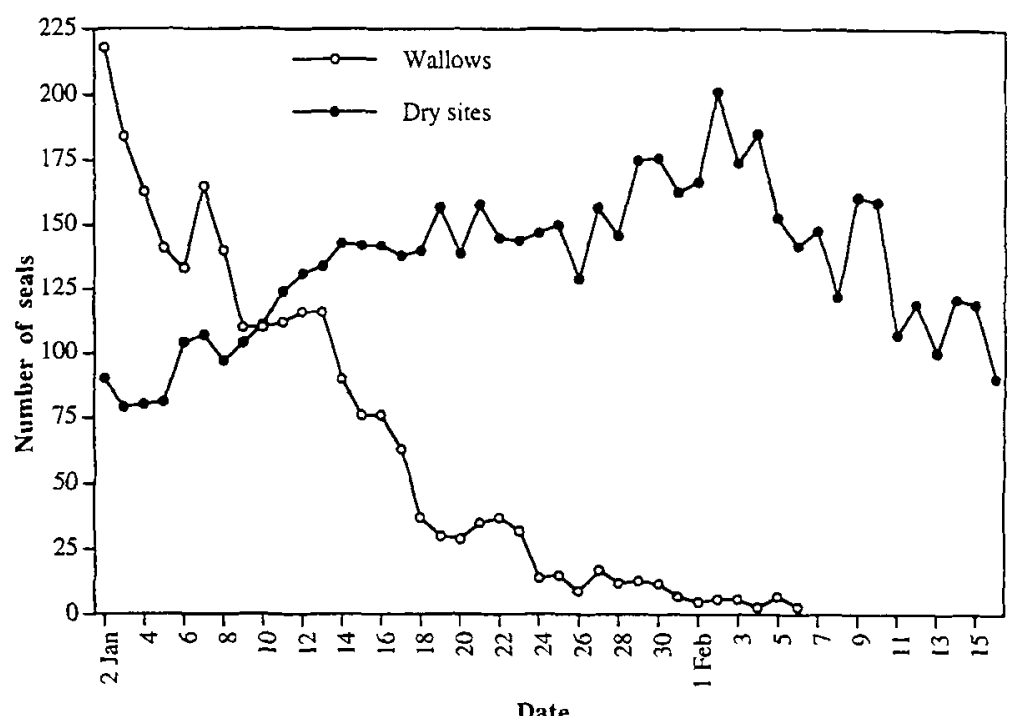


Table 1. Physical characteristics of the 17 moulting sites at Hannah Point, Livingston Island, South Shetland Islands.

\begin{tabular}{|c|c|c|c|c|}
\hline $\begin{array}{l}\text { Moulting } \\
\text { site }\end{array}$ & Ground cover & $\begin{array}{l}\text { Distance } \\
\text { from sea }\end{array}$ & $\begin{array}{l}\text { Wallow or } \\
\text { dry site }\end{array}$ & Notes and period of occupation \\
\hline$A a$ and $A b$ & $\begin{array}{l}\text { Waterlogged moss; } \\
\text { pools of water }\end{array}$ & $50 \mathrm{~m}$ & Wallow & $\begin{array}{l}\text { At least two seals were usually submerged in the pools of } \\
\text { water that were associated with this wallow. Abandoned } \\
\text { after } 24 \text { January. Means of } 50 \text { seals occurred between } 11 \\
\text { and } 16 \text { January. }\end{array}$ \\
\hline $\mathrm{Ba}$ and $\mathrm{Bb}$ & $\begin{array}{l}\text { Sand with pools of } \\
\text { water }\end{array}$ & $50 \mathrm{~m}$ & Wallow & $\begin{array}{l}\text { Nearby rock outcrop provided no shelter from the prevailing } \\
\text { winds. Abandoned after } 4 \text { January. } 22 \text { seals were counted } \\
\text { on } 2 \text { January, after which numbers declined. }\end{array}$ \\
\hline C & $\begin{array}{l}\text { Flat rocks and sand: } \\
\text { pools of water }\end{array}$ & $5 \mathrm{~m}$ & Wallow & $\begin{array}{l}\text { Abandoned after } 6 \text { February. Between } 2-8 \text { January, a mean } \\
\text { of } 82 \text { seals was recorded daily. Juvenile seals were also } \\
\text { observed outside the perimeter of the site. }\end{array}$ \\
\hline $\mathrm{D}$ & $\begin{array}{l}\text { Compacted sand } \\
\text { and copper breccia }\end{array}$ & $50 \mathrm{~m}$ & Dry site & $\begin{array}{l}\text { A pathway was worn from Site } D \text { to Site } E \text { below. Con- } \\
\text { tinuously occupied. Numbers ranged between } 3 \text { and } 17 \\
\text { throughout the entire period. }\end{array}$ \\
\hline E & Sand and shale & $5 \mathrm{~m}$ & Dry site & $\begin{array}{l}\text { A pathway led from the sea to the moulting site avoiding } \\
\text { the rocks. Continuously occupied. Between } 5-8 \text { seals were } \\
\text { counted daily before } 16 \text { January: between } 10 \text { and } 20 \text { seals } \\
\text { daily after } 16 \text { January. }\end{array}$ \\
\hline F & Compacted sand & $10 \mathrm{~m}$ & Dry site & $\begin{array}{l}\text { Continuously occupied. Numbers steadily increased until } \\
27 \text { January when } 71 \text { seals were counted. }\end{array}$ \\
\hline Gd & Pebble beach (dry) & $20 \mathrm{~m}$ & Dry site & $\begin{array}{l}\text { Both sites were located in a cove approximately } 20 \mathrm{~m} \text { wide } \\
\text { surrounded by cliffs } 5 \mathrm{~m} \text { high. }\end{array}$ \\
\hline Gb & $\begin{array}{l}\text { Pebble beach (with } \\
\text { puddles) }\end{array}$ & $10 \mathrm{~m}$ & Wallow & $\begin{array}{l}\text { Ga was continuously occupied. Peaks of } 45 \text { seals ( } 18 \\
\text { January) and } 41 \text { seals ( } 6 \text { February) were recorded. Gb } \\
\text { abandoned after } 5 \text { February. Peak of } 20 \text { seals on } 29 \text { January, } \\
\text { after which numbers declined. }\end{array}$ \\
\hline $\mathrm{H}$ & Sand with boulders & $70 \mathrm{~m}$ & Dry site & $\begin{array}{l}\text { Located on the crest of a gentle slope. Continuously occu- } \\
\text { pied. Means of } 23 \text { seals between } 21 \text { and } 28 \text { February, after } \\
\text { which numbers slowly declined. Still } 8 \text { seals on } 16 \text { February. }\end{array}$ \\
\hline $\mathrm{Ia}$ and $\mathrm{Ib}$ & Sand with boulders & $10 \mathrm{~m}$ & Dry site & $\begin{array}{l}\text { Continuously occupied. Low numbers until } 28 \text { January; } \\
\text { peak of } 54 \text { seals on } 2 \text { February. }\end{array}$ \\
\hline $\mathrm{Ja}$ and $\mathrm{Jb}$ & Flat rocks & $2-5 \mathrm{~m}$ & Dry site & $\begin{array}{l}\text { The two wallows were separated by a rock approximately } \\
40 \mathrm{~m} \text { high. Continuously occupied. Numbers between } 5 \text { and } \\
40 \text { until } 29 \text { January; peak of } 52 \text { seals on } 30 \text { January. }\end{array}$ \\
\hline $\mathrm{Ka}$ and $\mathrm{Kb}$ & Sand with boulders & $5 \mathrm{~m}$ & Wallow & $\begin{array}{l}\text { Abandoned after } 2 \text { February. } 52 \text { seals on } 2 \text { January, } 24 \text { on } \\
4 \text { January: } 44 \text { on } 7 \text { January; decline after } 8 \text { January. }\end{array}$ \\
\hline
\end{tabular}

The lower case letters indicate sites composed of two parts where seals were observed moving from one part to the other.

sites (D, E, F, Ga. H, Ia, Ib, Ja and Jb) were occupied continuously for the whole study period, while the remaining eight moulting sites $(\mathrm{Aa}, \mathrm{Ab}$, $\mathrm{Ba}, \mathrm{Bb}, \mathrm{C}, \mathrm{Gb}, \mathrm{Ka}$ and $\mathrm{Kb}$ ) were abandoned permanently by 6 February. Table 1 lists each moulting site with its physical characteristics. whether a wallow or a dry site. and its distance from the sea.

Fig. 2 gives the distribution of juvenile male seals when the sites are categorised by type into wallows and dry sites. The wallows had 221 juvenile males on 2 January, compared to 89 in the dry sites. (Of the remaining 29, 19 were hauled out away from the moulting sites - either moving from one site to another, or from the sea to a moulting site - and ten were in the water). The numbers of juvenile males in the wallows showed a steady decrease while the numbers of seals in the dry sites rose until a peak of 202 seals on 2 February, after which they too began to decline. This indicated a definite move from one type of moulting site to another. Subjective observations suggested that competition for places in the middle of the wallows was intense and that these were usually occupied by larger animals. Photographs indicated that seals at the dry sites, especially towards the end of January, were in the latter stages of coat shedding or in the postmoult phase. Photographs also showed that dry sites were less tightly packed than wallows, and 
that there was a great number of seals peripheral to the dry sites (i.e. that had been part of the pod but had moved away).

Juvenile males were still present at Hannah Point on 16 February, which may have been a result of unusual weather conditions reported in the 1993/4 season (Cruwys \& Davis 1994).

The juvenile male southern elephant seals at Hannah Point followed the basic pattern noted by Fedak et al. (1994); numbers in the wallows were higher earlier in the season (Fig. 2) and were abandoned when most seals were at the end of the coat-shedding phase, or entering the postmoult phase. Reasons for this behaviour possibly relate to the thermoregulatory requirements associated with moulting (Laws 1956; Boyd et al. 1993). Energy expenditure on moult has been estimated at 2.4 times the standard metabolic rate (Boyd et al. 1994), and it is clearly advantageous for seals to conserve heat by lying as closely to other animals as possible. The implication is that wallows enable the seals to maintain higher skin temperatures with less energy expenditure than is possible in dry sites. When the coat-shedding phase is complete, the seals no longer need to maintain high skin temperatures and move to dry sites where conditions are more favourable for new hair growth.

\section{Conclusions}

The data indicate that there is a general move from wallows to dry sites as the moult progresses. Thus the movements of the adult female southern elephant seals monitored by Fedak et al. (1994) correspond with the movements of the juvenile males at Hannah Point. The largest concentrations of seals occurred initially in wallows that were abandoned after 6 February. Numbers in dry sites increased throughout January, and these sites were still occupied on 16 February. These are tentative conclusions based on data from a single season, and more research is necessary to ascertain the precise movements of individual seals from site to site and within wallows.

Acknowledgements. - This research was funded by the Jephcott Charitable Trust, the Foreign and Commonwealth Office, and the Trans-Antarctic Association. We thank B. Stonehouse for providing us with the opportunity to conduct this research, and B. Riffenburgh, G. Marshall and S. Wells for helping with data collection. Additional thanks to G. Marshall for producing the maps, and to the two anonymous referees for constructive comments on the manuscript.

\section{References}

Boyd, I. L., Ambom, T. A. \& Fedak, M. A. 1993: Water flux, body composition and metabolic rate during moult in female southern elephant seals (Mirounga leonina). Physiol. Zool. $66,43-60$.

Boyd, I. L., Arnbom, T. A. \& Fedak, M. A. 1994: Biomass and energy consumption of the South Georgia population of southern elephant seals. Pp. 98-117 in Le Boeuf, B. J. \& Laws, R. M. (eds): Elephant Seals: population ecology, behaviour and physiology. University of California Press, Berkeley.

Carrick, R., Csordas, S. E., Ingham, S. E. \& Keith, K. 1962: Studies on the southern elephant seal, Mirounga leonina (L.). III. The annual cycle in relation to age and sex. CSIRO Wildlife Res. 7(2), 119-160.

Cruwys, E. \& Davis, P. B. 1994: Southern elephant seal numbers during moult on Livingston Island, South Shetland Islands. Polar Rec. 30(175), 313-314.

Cruwys, E. \& Weinstein, D. 1993: Aerial survey of walrus haulout sites in west Spitsbergen and Moffen. Polar Rec. 29(169), 55-58.

Fay, F. H. \& Ray, G. C. 1968: Influence of climate on the distribution of walruses, Odobenus rosmarus [Linneaus]. I. Evidence from thermoregulatory behaviour. Zoologica 53 , 1-18.

Fedak, M. A., Arnbom, T. A., McConnell, B. J., Chambers, C., Boyd, I. L., Harwood, J. \& McCann, T. S. 1994: Expenditure, investment, and acquisition of energy in southern elephant seals. Pp. 354-373 in Le Boeuf, B. J. \& Laws, R. M. (eds): Elephant Seals: population ecology, behaviour and physiology. University of California Press, Berkeley.

Hindell, M. A. \& Burton, H. R. 1988: Seasonal haul-out patterns of the southern elephant seal (Mirounga leonina). at Macquarie Island. J. Mammal. $69(1), 81-88$.

King, J. E. 1983: Seals of the World. 2nd edition. Oxford University Press and the British Museum (Natural History). Oxford and London. $240 \mathrm{pp}$.

Laws, R. M. 1956: The elephant seal (Mirounga leonina Linn.). II. General, social and reproductive behaviour. Falkland Islands Dependencies Survey Scientific Reports 13. 88 pp.

Le Boeuf, B. J. \& Laws, R. M. 1994: Elephant seals: an introduction to the genus. Pp. 1-26 in Le Boeuf, B. J. \& Laws, R. M. (eds): Elephant Seals: population ecology, behaviour and physiology. University of California Press, Berkeley.

Ling, J. K. \& Bryden, M. 1981: Southern elephant seal. Pp. 297-327 in Ridgway, S. H. \& Harrison, R. J. (eds). Handbook of Marine Mammals. Academic Press, London.

Matthews, L. H. 1929: The natural history of the elephant seal with notes on other seals found at South Georgia. Discovery Rep. 1, 233-256.

Rand, R. W. 1967: The Cape fur seal (Arctocephalus pusillus) 3. General behaviour on land and at sea. Republic of South Africa, Department of Commerce and industries, Division of Sea Fisheries, Investigative Report 21.

Scheffer, V. B. 1958: Seals, sealions and walruses: a review of the pinnipedia. Stanford University Press and Oxford University Press, Stanford and London. 179 pp.

Tierney, T. J. 1977: The southern elephant seal, Mirounga leonina (L.), in the Vestfold Hills, Antarctica. Aust. Wildlife Res. 4, 13-24.

Wartzok, D. 1991: Physiology of behaviour in pinnipeds. Pp. 236-299 in Renouf, D. (ed): The Behaviour of Pinnipeds. Chapman and Hall, London. 
